\title{
IDENTIFYING LEVEL OF HISTORICAL CONSCIOUSNESS OF COLLEGE STUDENTS OF HISTORY EDUCATION IN TERMS OF ETHNICITY, ESPECIALLY JAVANESE AND MINANGKABAU
}

\author{
Aisiah, Sumarno \\ Padang State University/PEP UNY 10701261002, Yogyakarta State University \\ aisiah.unp@gmail.com, and sumarno_unj@yahoo.co.uk
}

\begin{abstract}
The purpose of this study was to identify level of historical consciousness of college students in Indonesia in terms of ethnic groups, particularly Javanese and Minangkabau ethnics. Historical consciousness is measured by four aspects, namely knowledge of historical events, understanding of historical research methods, finding meaning of historical events and viewing historical usefulness. Subjects were Javanese college students, represented by history education college students of State University of Yogyakarta and Minangkabau college students represented by history education college students of Padang State University. The research data were collected through historical consciousness test. Test instruments were formulated in the form of multiple choice questions associative consisting of knowledge about historical events, understanding of historical research methods, finding meaning of historical events and viewing usefulness of history. The data were analyzed by the percentage of the average scores level of historical consciousness on both ethnics group of college students. Overall, result analysis showed that percentage score of historical consciousness of Javanese college students is $42 \%$ higher than college student of Minangkabau i.e. 39\%. It means that the level of historical consciousness of Javanese college students higher than Minangkabau college students.
\end{abstract}

Keywords: historical consciousness, Javanese college students, Minangkabau college students

\section{Introduction}

This paper highlight contemporary issues about quality and equity of education in a pluralistic society especially Indonesia. Specifically this paper focused on historical consciousness of Javanese and Minang ethnics with historical offending both ethnics in the struggle formed and built nation-state of Indonesia, of course without ignore the important role of other ethnic groups. The implication is related to the evaluation of historical education in this nation, so that the younger generations do not forget about history of their nation as one of the unifying factor of the nation in the reality of mix society.

Indonesian nation in the global level is known as a very pluralistic nation because the society is so plural in terms of ethnics, cultures, and religions. More than 300 ethnics live in the Unitary State Republic of Indonesia (USRI). At first glance, all ethnics look the same, even difficult determine where Javanese, Batak, Sundanese, Minang, Dayak, Bugis, Madurese, and other ethnics. The differences appear when they're talking and more apparent after traced more details about the "way of thinking" and "philosophy" of each ethnic.

Mochtar Naim distinguished scattered ethnic groups in Indonesia in two characteristics that is Minang and Javanese character. Javanese character reflects the characteristic of hierarchical, symbolic feudalistic, and centralistic societies. In contrast Minang character reflects the characteristics of democratic, fundamentalist, rational, open and decentralized societies. Bahder Djohan claimed both of this polarization has long existed in Indonesian history. It is not coincidence in the history that Javanese and Minang ethnics have played an important role together in Indonesian history. Indonesian historical sheets have filled by the fragrant names of both ethnics [1].

Historical facts show that both ethnic groups cooperate with each other against Dutch Colonial. Many national and even international caliber figures come from both. They are known in various things. In the matters of religion and movement, beside Diponegoro, Cokroanminoto, Samanhudi (Javanese figures) there were Tuanku Imam Bonjol, Agus Salim and Abdul Muis. From nationalist, beside Soekarno, Sartono, or Ali Sastro (Javanese ethnic) there were also figure Hatta, Sjahrir, and Yamin. In terms of religious leaders and education, both ethnic groups also have their own representatives figures, aside Ahmad Dahlan (Javanese), on other side there were also Hamka, Sjafe'i, Natsir, Hanifa and others (Minang). No less exceptional figure of women also took part, there was Kartini as Javanese woman, Siti Rohana Kudus and Rasuna Said as Minang woman.

Since the beginning, actually Javanese and Minang ethnics complementary and need each other even though occasionally seen 'competition', especially in terms of way of thinking. Probably, typical of both ethnic groups perfectly represented by the existence of dual-single figure Soekarno-Hatta. On 
one side, Soekarno symbolizes the personality and way of thinking Javanese ethnic, in other side Hatta represent the personality and way of thinking Minang ethnic.

Although geographically Javanese and Minang came from distinct region (Minang came from West Sumatra area), but both are able to coexist and complement each other. This is seen from habit of Minang ethnic who like migrated to Java region. In the seacoast, Minang ethnic mostly studying and trading. Minang etnich, at least able to blend in with Javanese which were mostly living and settle on the Java island. Both of region ethnic origin equally was once the center of government, even-though in Minang region was in form of emergency government (Emergency Government of Indonesian Republic/EGIR).

Historical facts prove that in the physical revolution era (1945-1950) against the Dutch Colonial, administrative center Republic of Indonesia had experienced the displacement in region of origin Javanese and Minang ethnics. In origin region Minang, ever lasted emergency government when the center of the government in Yogyakarta was occupied by Dutch Colonial. Previously, since the proclamation of independence on August $17^{\text {th }}$, 1945, the administrative center of the government located in Jakarta. But because Dutch Colonial want to have power back in Indonesia and occupied Jakarta capital on September $29^{\text {th }}$, 1945 , then on January $4^{\text {th }}$, 1946 central of the government was moved to Yogyakarta. However, in turbulent times, the Dutch also occupied Yogyakarta capital in $2^{\text {nd }}$ Dutch military aggression dated on December $19^{\text {th }}$, 1948, and even captured Soekarno-Hatta as a President and vice President Republic of Indonesia.

Hatta immediately sent a letter to Syafruddin Prawinanegara wire and gave mandate to lead the immediate emergency government in Sumatra. Since December 1949, the emergency government took place under the Sjafruddin Prawiranegara leadership on the earth of Minang ethnic until the Yogyakarta capital successfully retaken and seat of government returned to Yogyakarta capital on July 1949 [2]. By doing so, for approximately eight months, Minang ethnic area has become the center of emergency government in difficult times to save the sovereignty of Indonesian nation that has been proclaimed since 1945 .

Historical facts also indicate that government control almost all dominated by the Javanese ethnic, but Minang ethnic has also held the reins of government, especially during the period Republic of Indonesian Union (RIU) on December $27^{\text {th }}, 1948$ until August $15^{\text {th }}, 1950$. At the time of RIU, Mr. Assa'at as the Minang people had been believed to be the functionaries while the President Republic of Indonesia as part of the RIU countries [3]. Eventhough Mr. Assa'at's positions as acting president Republic of Indonesia (as long as RIU period) is still debated and not formally written in Indonesia historical book school, but the historical evidence shows that Mr. Assa'at as Minang ethnic has had important role in the government of Indonesia in the past. On the other hand, It is not be denied that position of president since the independence of Indonesia as a whole dominated by Javanese ethnic.

Talking about Java and Javanese ethnic indeed an interesting thing viewed from various sides. In terms of history, from prehistory to the present, various historic events in Indonesia as a nation much have happened in the area of Java ethnic origin. Java island is a prehistoric center and from there discovered ancient of human fossils. Java island became the center of international trade of ancient era, the center of Hindu-Buddhist religious development, even until the arrival and spread of Islam by Wali Songo. Java island is also the power bases Dutch Colonial rule and implementation of the forced cultivation systems because of extensive agricultural land and fertile. Besides that, Java island also became the center of the movement Indonesian people's struggle to gain independence [4]. In Java by itself, Javanese ethnic have been a lot of experiencing and fill historical sheet in the collective life of Indonesian nation, although other ethnic groups are also experienced the same thing.

Minang area viewed from the background of history also has its own uniqueness. The coastal areas of West Sumatra, included West Sumatra now had ever been a port city in international trade activities, especially after Islamic religion entered. Islam also had pushed the progress of economic societies. Minang area then known as a producer of gold, coffee, and gambier [5]. Even Islamic clerics Minang Dato' Ribandang has spread Islam to GoaTallo kingdoms in Sulawesi island [6]. Ethnic Minang on the other hand, no doubt also have an important role and significant contribution in the spirit of nationalism and the establishment of the Indonesian nation that is free from colonial rule [7].

Indonesian history on the movement period and revival national proved that anti-colonial movement that first emerged were from Java and Minang (Sumatra). Both emerged as the leaders of nation transformation has obvious reasons. Java has high social change. While Minang was the first region which was experienced by Islamic reform in Indonesia under the Paderi leadership has been experienced a major change since the arrival of the Dutch Colonial. Migration tradition and establish relationship with the outside world make Minang ethnic open to new ideas [8]. In terms of education, Javanese and Minang ethnics who have endured West education well aware of the condition as colonized nation. Both ethnics group indomitable struggling to break away from the shackles of colonizers.

In its development after independence, Java is precisely became the target of other ethnics hatred 
in various regions in Indonesia. The hatred of other ethnic was caused by dissatisfaction to the central government policies which were considered unfair. This can be monitored on inequality of physical construction and imbalance in the management of available resources. As an impact, the gap appeared too wide and implicated on the foundations of social life, economics, politics, law and education.

Gaps in various areas of public life, especially Java and the outer (center and region) have caused nation disintegrated problems. Historical facts proved various kinds of upheavals ranging from Revolutionary Government Republic of Indonesia (RGRI), Republic of South Maluku (RSM), Free Aceh Movement (FAM), Free Papua Organization (FPO), and all of ethnic and religious conflicts were impact of various gaps in community life and threatening the integrity Republic of Indonesia. Fairness, equality, concord, and prosperity live

together become the most essential thing to be improved in Indonesian community at this time.

There are many efforts that can be done to attain justice and equality for all communities in Indonesia. Although the gap also occurs in the field of education, but education has potential to actualized justice, equality and peace even the welfare of all groups of Indonesian societies. Education plays an important role in shaping a fair society, where equal rights are just not understood in shallow political issues but also in economic and cultural terms. Equal rights with regard to the issue of access, opportunities and influences. Education can reduce even tackling the source of imbalance in societies [9]. Education provides opportunities to actualize equality access, opportunity and influence life together in various fields. In historical education, this effort can be realized by strengthening historical consciousness Indonesian people, especially young generations and intellectuals because they have capacity to unite all sections of society.

Young peoples and intellectuals of this nation trained to remember, analyze and take lessons from historical experience together in a diversity nation. Past experience of nation's predecessors teaches about how to behave and work together regardless of differences in ethnics background, culture and religion in order to build life together as a sovereign nation and equal with other nations. Lessons from previous generation obtained by studying history.

Studying history of Indonesia peoples from era to era, of course can be known the development viewed from various walk of life together. Portraits and facts about inequality or injustice as well causality will also be uncovered. This knowledge will certainly arouse historical consciousness, especially collective consciousness. This kind of historical consciousness is able to arouse feelings social and moral responsibility towards all forms of development of the nation [10]. The expectation in the future imbalances in Indonesian societies can be overcome and a sense of justice can be enjoyed.

For the younger generation now, especially those who studying history are certainly not easily lost in memory, especially about the various ethnic groups who had been united struggled against invaders in order to live together in the Homeland. Minang and Javanese ethnics are two among other ethnics in Indonesia who were active struggled for independence. The leaders of both ethnics group has equally been proving loyalty, togetherness and sacrifice to the nation. Although Minang ethnic classified as minorities than majority Javanese ethnics based on the total number of Indonesian societies, but both were able to show equality in liabilities as citizens. Both ethnics of course have a remarkable historical consciousness and have had demonstrated highly the sense of moral and social responsibility.

Now, the next question is how about the level of historical consciousness of young generations of Javanese and Minang ethnics currently, whether by studying nation history, they have had qualified historical consciousness as a provision to build this nation in the future with a sense of justice. This question will be discussed further through the results of the research that has been done. The research question is how about level of historical consciousness of college student from Javanese and Minang ethnics seen from four aspect; knowledge of historical events, understanding of historical research methods, finding meaning of historical events and viewing historical usefulness?

\section{Theoretical Review}

The concept of historical consciousness in a simple is stated by Lukacs [11] as the remembered past [12]. Carlob stated historical consciousness deeper how people perceive the past. Historical consciousness according to Lukacs emphasized on memory (knowledge) and related to the historical events. While Paska stated historical consciousness is not just merely remember past (events), but how does interpret (significance) the historical events in order to feel the usefulness.

At individual level, historical consciousness is the basic ability to recall and imagined past events [13]. Remembered the past according to Lukacs involves cognition and recognition which is closely related to the process or activity of thought. Historical consciousness as a process of thinking for Ankersmith [14] is characterized by the consciousness that the past painting as an intellectual discourse dependent on particular factual accuracy. Lukacs, Carlob and Ankesmith viewed historical consciousness rests on the memory of past events based on factual particular information.

Another view about historical consciousness concept according to some Indonesian Historians were discussed in the book "Thoughts on Coaching 
Historical Consciousness" the ministry of education and culture of Indonesia [15]. Abdulgani in detail defines historical consciousness as a mental attitude to be active in the dynamic of knowledge about historical facts and causalities, the logic of history, and the increase in conscience with the lesson, discernment and wisdom to reflect the past experiences. Soedjatmoko also view historical consciousness with regard to the attitude of the soul, but it is concerned with how to face reality in the perspective of present time, past, and future. It means that historical consciousness is related to the usefulness of history or how to act on the reality of time.

Historical consciousness according to Lapian interpreted as a purification of history, the study of the elementary things about 'what', 'who', 'when', 'where' 'why', the image of history and it function in education. For Leirissa and Lapian views, historical consciousness simplified as an understanding of the nature of historical studies. While, Ayatroehadi viewed historical consciousness as an insight into history and ideas therein, theoretical and methodological foundation historical research and criticism written/spoken about history.

Indonesian historians viewed historical conssciousness in various dimensions. Lapian, Leirisa, and Ayatroehadi looked at the concept of historical consciousness as an event and as a science, such as understanding theory and methodology of historical study in investigating events. While Abdulgani and Soedjatmoko tend to saw historical consciousness related to significance (importance) and usefulness of history as the study of past experiences and past realities interconnection with the present and future.

The views and opinions historian about the concept of historical consciousness is essentially lead to simple formula that historical consciousness is condition/process of thinking whereby someone recalled historical meaning and historical usefulness. Operationally, historical consciousness can be measured from four things (see fig. 1).

Historical consciousness begins from knowledge of historical facts, and even must also plus with the knowledge of the causal between the facts [16]. Historical knowledge is prerequisite for the formation of historical consciousness, and historical consciousness strongly influences production of historical knowledge [17]. Historical knowledge comes from the study of historical events; even historical knowledge is evidenced by the robustness of the findings [18]. Historical knowledge gained based on the results of a study from accurate and credible historical sources. The results of historical research can reinforce historical consciousness. Historical consciousness enhanced through the studying important historical events. Historical events generate emotions, values, and specific ideas or thoughts that make life meaningful. Historical consciousness is related to giving meaning to the historical events.

The meaning of events lies in the significance of that event [19]. Significance of events indicated by the values contained in it's events and the impact of such events. The ability in finding significance of events and it values contains reflects deep historical consciousness and at this level historical consciousness is not merely derived from knowledge of historical facts, but comes from a deep understanding about significance of historical events. By knowing and finding significance historical events, a person can learn and act better in the future [20].

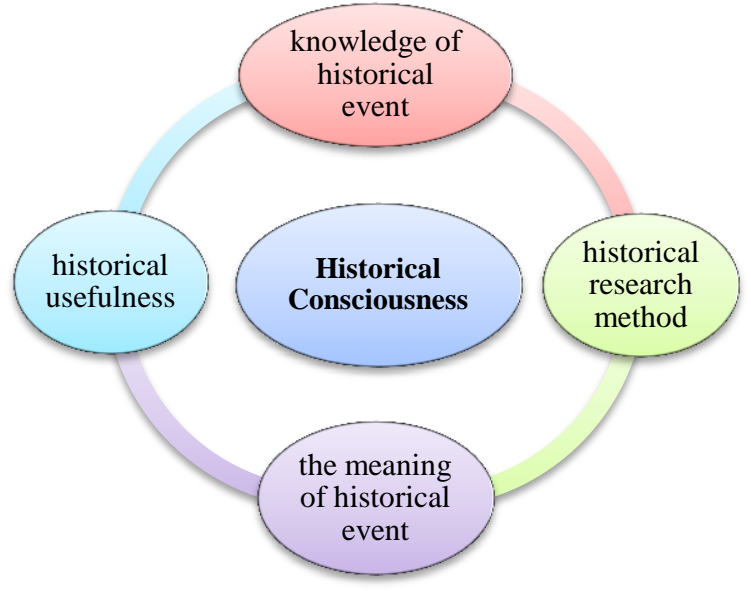

Figure 1. Construct of Historical Consciousness (Theoretical Review Result)

Fig. 1 presents four aspects of historical consciousness. First, knowledge of historical events is the knowledge of what has happened in the past, as well as reconstruction of past actions at this time. According S. Kartodirdjo, historical knowledge is unfolding of events with the overall facts, include; what, who, where, when, and how. Historical knowledge lies not in what it can tell about future, but on what it can tell about past [21]. Historical knowledge can be measured through what is remembered about the facts that have been studied [22]. The linkage between historical facts will result deep knowledge of the events. Intellectual curiosity about past is a reason why people learn and read history [23]. Historical Knowledge is part of historical understanding in sense of substantive and procedural knowledge of historical disciplines [24]. Historical knowledge is gained from the results of historical research.

Second, historical research method is the use of series scientific procedures to verify evidence or historical sources. This procedure covers; heuristic, source criticism, interpretation and exposition in written form. Historical source is historical material that could shed light the story of human life or remains of human life and trace of the results from human activity both physical and non-physical [25]. Historical sources consist of primary and secondary 
sources. If historical sources has been found, next activity is source criticism as verification or testing accuracy or truth of sources [26]. Source criticism consists of external and internal criticism (authenticity and credibility). Authenticity and credibility testing is verification, validation, or confirmation in order to obtain information that can be accounted in process interpretation and historical writing (historiography). Historiography is the last step process of historical research. By reading historical research result, we knew past events and it's significance.

Third, meaning of historical events is significance of historical events viewed from application of value in particular perspective [27]. Meaning of historical event is found by knowing complexity of events. The meaning does not appear as part of a fact [28]. Efforts to train ability in finding meaning of historical events are something that exceeds the simple knowledge-based content. The meaning of historical events appears by knowing what had happened and had done before and its significance [29]. Everyone can protect themselves by studying and knowing past events and then use it to build a better life. There are many uses of history in life.

Fourth, Historical usefulness is the benefits to be drawn from history. The value of historical usefulness can be classified become theoretical and practical uses. Theoretical usefulness relates to the use of history as the intellectual exercise, academic needs, and scientific interests. Historical knowledge is based on practical needs of human life. Practical usefulness of historical lesson can be seen from its characteristic, such educative, instructive, inspiring, and recreation. History is usefull for educational purposes, as well as moral lessons and teaching materials in forming attitudes and actions that exemplary or avoided from historical experience. Read biographies or autobiographies can be motivated, giving inspiration, spirit, consciousness, and ideas or solutions in facing the difficulties in life. Besides that, reading history also gives pleasure and evocative sense of aesthetic, open your heart and feeling deliciously nostalgic and get acquainted with the past [16], [23], [26], [30] [31]. By studying history, people being creative to face the challenges of times. History is a repository of experience on which to base future projections and predictions of future events [32]. History became spectacles to see the future and compass directions for progress in formulating decisions and anticipating all of possibilities that will occur in the future.

\section{Research Method}

This study used quantitative research method. Research subjects were Javanese and Minang college student ethnics. Javanese college students taken from history education department Yogyakarta State University (YSU), while Minang college students drawn from history education department Padang State University (PSU). Research subjects were taken through stratified sampling, i.e. college students the $1^{\text {st }}$ and $3^{\text {rd }}$ year.

Table 1. Research Subjects

\begin{tabular}{|l|c|c|c|}
\hline $\begin{array}{l}\text { Ethnics } \\
\text { Year }\end{array}$ & Javanese & Minang & Amount \\
\hline First & 20 & 8 & 28 \\
\hline Third & 16 & 26 & 42 \\
\hline Amount & 36 & 34 & $\mathbf{7 0}$ \\
\hline
\end{tabular}

Data collection about college student historical consciousness of Javanese and Minang ethnics done through the historical consciousness test in the form of associative multiple choice. Test instrument consists of four devices, i.e knowledge of historical events, understanding of historical research method, finding meaning of historical events and viewing historical usefulness. Content validity instruments analyzed by Aiken's formula [33]. Content validity index of instrument (v) obtained from calculation sum of score six raters (n) in Likert scale four categories (c).

$$
\mathrm{V}=\frac{\mathrm{s}}{[\mathrm{n}(\mathrm{c}-1)]}
$$

The criteria for determining content validity done by comparing the value of $\mathrm{V}_{\text {calculated }}$ and the value of $\mathrm{V}_{\text {table. The value of }} \mathrm{V}_{\text {table }}$ is the minimum index of content validity which is viewed from the number of raters and rating categories (see. table $\mathrm{V}$, Aiken). Because of number raters were six and number rating categories were four, then minimum value of content validity index in table $\mathrm{V}$ was 0.78 . Content validity index of historical consciousness can be seen in table 2 below.

Table 2. Content Validity Instrument of Historical Conscciousness

\begin{tabular}{rrr}
\hline Instrument Aspects & $\mathbf{V}_{\text {calculated }}$ & Decision \\
\hline 1. Knowledge of historical events & 0.78 & Valid \\
\cline { 2 - 3 } 2. Understanding of historical method & 0.78 & Valid \\
\cline { 2 - 3 } 3. The meaning of historical events & 0.78 & Valid \\
4. Historical usefulness & 0.78 & Valid \\
\hline
\end{tabular}

Reliability instrument analyzed by using Alpha Cronbach through SPSS.17 software. Coefficient reliability Cronbach's Alpha 0.789. It means that instrument of historical consciousness can be said reliable.

Table 3. Table 3. Reliability instrument

\begin{tabular}{|r|r|}
\hline Cronbach's Alpha & \multicolumn{2}{|c|}{ N of Items } \\
\hline .789 & \\
\hline
\end{tabular}




\section{Research Result}

Data test of historical consciousnesses were analyzed by using percentages technic to identify level of historical consciousness between college students of Javanese and Minang ethnics. The results of the study described as follows.

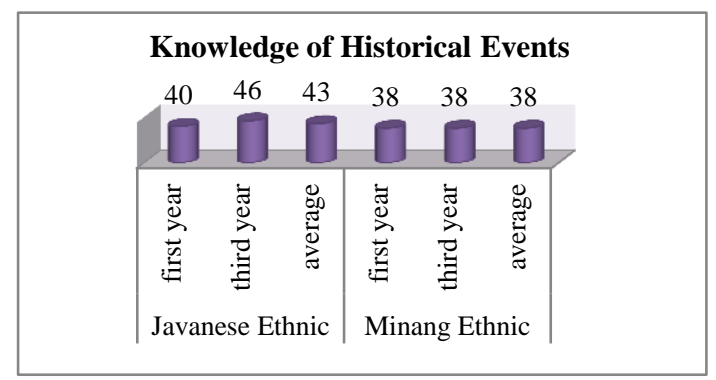

Figure 2. Percentage Level Mastery of Historical Knowledge of College Student of Javanese and Minang Ethnics

Fig. 2. shows identifying result of percentage historical consciousness level between Javanese and Minang college students. Average of mastery historical knowledge college students Javanese $43 \%$, while Minang college students $38 \%$. It means that level of historical consciousness Javanese college students on aspect historical knowledge is higher 5\% from Minang college students. It can be understood if viewed in terms of quality education and availability readings source. In Java, especially in Yogyakarta, quality education and availability learning resources (reading materials) better than in West Sumatra (Minang).

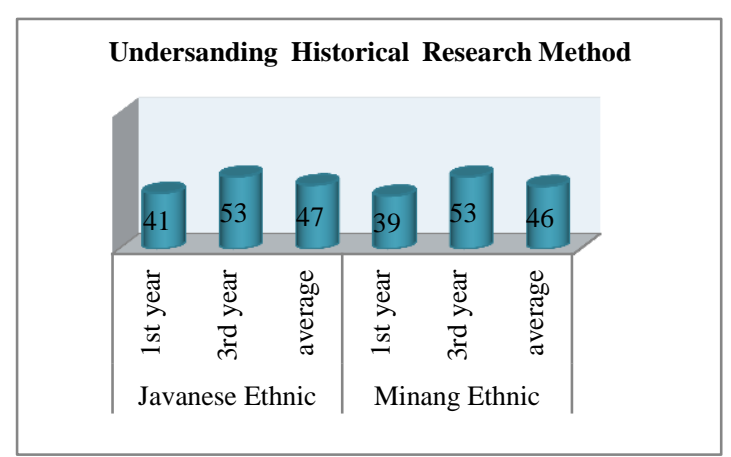

Figure 3. Percentage Level Understanding College Students ethnic of Javanese and Minang on Historical Research Method

Fig.3. shows that Javanese college students understanding about historical research methods do not much differ from Minang college student. The differences of both ethnics only $1 \%$. Average understandings on historical research method of Javanese college students $47 \%$ Javanese, while Minang 46\%. It means that understanding both college students ethnic can be said to be at an equal level. It show both ethnic groups have the same ability to understand the procedures working of historical research.

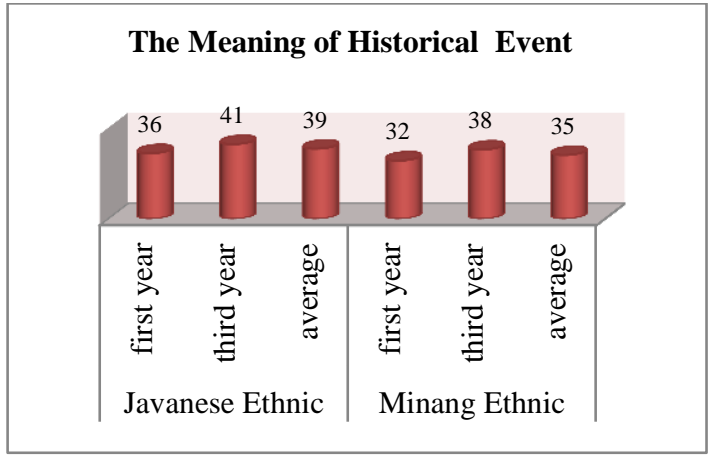

Figure 4. Percentage Level of Ability College Students of Javanese and Minang Ethnic in Finding Meaning Historical Events

Fig.4. shows percentage level historical consciousness viewed from aspect the meaning of historical events between Javanese college students and Minang. Giving meaning of historical events is characterized by the ability in finding significance such values or impact of historical events. Javanese college students have better ability in finding meaning of historical events than Minang college students. Average percentage of Javanese college student ability in discovering significance of historical events $58.5 \%$ higher compared with Minang college students' ability 35\%. Javanese college students superior $3.5 \%$ in finding meaning or significance historical events.

Perchance, this can be understood by tracing back national Indonesian history. No doubt that since prehistoric era, the Hindu-Buddhist kingdoms era, the period of arrival and Islamic civilizations, Colonial era, national movement era and revolution, Old Orde, New Orde until Reformation, Javanese plays an important role in Indonesian history. Of course, the historical experience spawned its own meaning for Javanese ethnic. No wonder if Javanese ethnic has relatively better ability in finding meaning historical evets from their predecessors' historical experience.

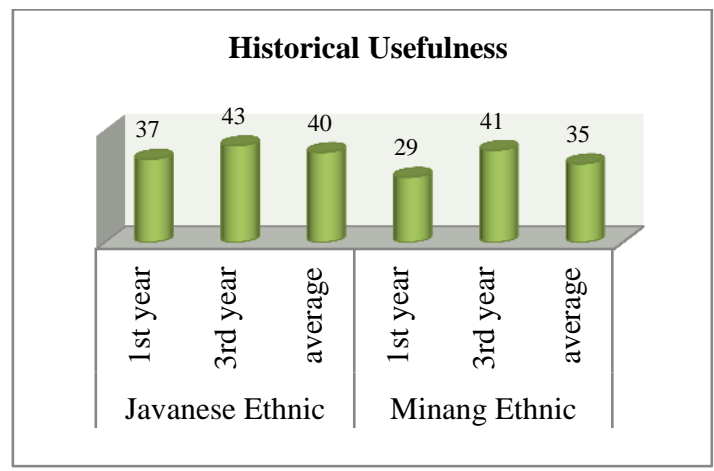

Figure 5. Percentage Level of Ability Javanese College Students and Minang College Students in Viewing Historical Usefulness 
Historical consciousness of Javanese and Minang college students on aspect of historical usefulness as seen in fig. 5 shows the difference $5 \%$, ie $35 \%$ and $40 \%$. The average percentage of Javanese college student abilities in viewing historical usefulness $40 \%$, while Minang college students $35 \%$. It means Javanese college students have higher ability in viewing historical usefulness. Avalability of historical books and resources in Java, especially in Yogyakarta had given good chance for the javanese college students to read more historical books and visit historical site. They can view dan feel practical use of history for their ability.

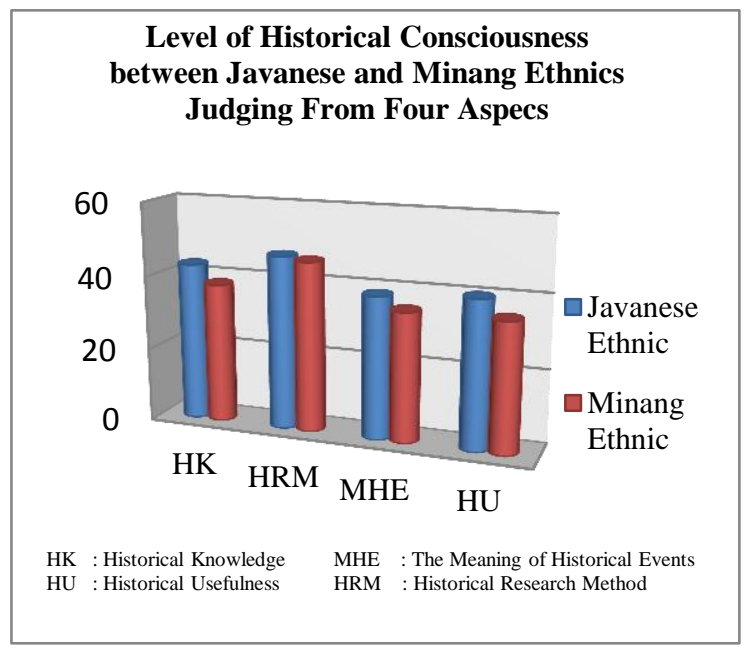

Figure 6. Percentage Level of Historical Conscious-ness Javanese and Minang College Students Ethnics

Percentage of identification results of historical consciousness level between Javanese and Minang college students showed in fig. 6. As a whole, level of historical consciousness of Javanese college students higher than Minang college students in four aspects highlighted. Significance of this differ more analyzed through compared mean between two ethnic groups. The significance of mean scores differences both of ethnics groups were analyzed through t-test by using SPSS.17 software (see. Table below)

Table 4. Independent Samples Test

\begin{tabular}{|c|c|c|c|c|c|c|c|c|c|c|}
\hline & \multirow{2}{*}{\multicolumn{2}{|c|}{$\begin{array}{c}\text { Levene's } \\
\text { Test for } \\
\text { Equality of } \\
\text { Variances }\end{array}$}} & \multicolumn{7}{|c|}{ t-test for Equality of Means } \\
\hline & & & & & & & & & $\begin{array}{r}95 \% \\
\text { Confid } \\
\text { Interval } \\
\text { Differ }\end{array}$ & $\begin{array}{l}\text { \% } \\
\text { dence } \\
\text { lof the } \\
\text { ence }\end{array}$ \\
\hline & & F & Sig. & $\mathrm{t}$ & df & $\begin{array}{l}\text { Sig.(2- } \\
\text { tailed) }\end{array}$ & $\begin{array}{c}\text { Mean } \\
\text { Differ } \\
\text { ence }\end{array}$ & \begin{tabular}{|c|} 
Std. \\
Error \\
Differe \\
nce
\end{tabular} & Lower & Upper \\
\hline Score & $\begin{array}{l}\text { Equal } \\
\text { variances } \\
\text { assumed }\end{array}$ & 1.817 & .182 & -.368 & 68 & .714 & -.805 & 2.191 & -5.178 & 3.567 \\
\hline & $\begin{array}{l}\text { Equal } \\
\text { variances } \\
\text { not } \\
\text { assumed }\end{array}$ & & & -.370 & 65.479 & .712 & -.805 & 2.175 & -5.149 & 3.538 \\
\hline
\end{tabular}

T-test result shows that, at $\mathrm{df}=68$, value sig. $0.182<0.05$, it mean level of historical consciousness between Javanese college students and Minang not differ significantly. It can be said that the level of historical consciousness Javanese college students equal as Minang college students. Although percentage level historical consciousness of Javanese college students higher 3\% from Minang, but this differences is not significant.

\section{Conclusion}

The identifying results shows that the level of historical consciousness of Javanese college students aqual with Minang college students. Overall level of historical consciousness both ethnics were on fairly high condition. This is become alarming for Indonesian society as a multi-ethnic nation. During this time, it's believed that one of the unifying factors of Indonesian nation-state is due to historical factor. If historical consciousness of Indonesian young generation is at an alarming level, continuation of the nation's life of course will be at stake. It warrant concern by various parties. Do not let the young generation forget history of their own nation.

\section{Suggestions}

Based on this research study, researchers proposed following suggestions. First, government policies need to accommodate all groups of society in order that equality and justice continue to be improved, such as the renewal of history education curriculum focuses on role and cooperation of individuals or ethnic groups in Indonesia. Assa'at as Minang figures who had proved his contribution to Indonesian nation-state, but have not received the recognition it deserves, even still debated.

Properly, while there was accurate evidence and no contrary to Pancasila and the Constitution, the Government needs to adopt policies in order that justice is perceived by Minang ethnic or other ethnic in same case. Third, Campus (especially in Java) needs to accommodate learning community multi-ethnic/cultural to accommodate all college students from diverse ethnic groups from Java outside. Ethnics differences of course affect the methods, ways of teaching, medias, and learning environment. Values relating to social justice needs to be emphasized such as equality, tolerance, and careness [9].

\section{Future Research}

Other researchers can conduct similar research to identify level of historical consciousness of other ethnic college students in Indonesia, for example, Batak, Sundanese, Bugis, Madurese college students, and so on. Such research is expected to strengthen historical consciousness of individual nor collective as a nation' generations. 


\section{REFERENCES}

[1] Mochtar Naim, "Bahder Djohan sebagai manusia Minang”, Unpublished.

[2] Kementerian pendidikan dan Kebudayaan RI, Indonesia dalam Arus Sejarah: Perang dan Revolusi, jilid 6, Jakarta: PT Ichtiar Baru van Hoeve, 2012.

[3] Anshar Firman Haryadi. "Mr. Assaat: saudara acting presiden," in press.

[4] Anoname. "Java," free Encyclopedia, Unpublished.

[5] Robert Cribb \& Audrey Kahin, Historical Dictionary of Indonesia. USA: Scarecrow Press, Inc, 2004.

[6] Kementerian pendidikan dan kebudayaan RI, Indonesia dalam arus sejarah: perang dan revolusi, jilid 3, Jakarta: PT Ichtiar Baru van Hoeve, 2012.

[7] Yuliandre Darwis, "History of Minang-kabau Press," Unpublished.

[8] M. C. Ricklefs, A History of Modern Indonesia since 1200, Britain: Palgrave, 2001.

[9] L. Bell and H. Stevenson, Education Poli-cy: Prosess, Themes and Impact, London: Routledge, 2006.

[10] Sartono Kartodirdjo, Pendekatan Ilmu Sosial dalam Metodologi Sejarah, Jakarta: Gramedia Pustaka Utama, 1992.

[11] John Lukacs, Historical Consciousness or The Remembered Past. London: Harper \& Row Publisher, 1968.

[12]L. M. Paska, "Does film affect learning engangement?: historical inquiry and the document-based question in middle school social studies classroom," Unpublished.

[13] Carlob \& Straub, "Historical consciousness in youth: theoretical and exemlplary empiri-cal analysis," in Forum Qualitative Social Research, vol. II pp. 1-49, September, 2001.

[14] Ankersmith, Refleksi tentang Sejarah: Pendapat-Pendapat Modern tentang Filsafat Sejarah, Jakarta: Gramedia,1987.

[15] Kementerian Pendidikan dan Kebudayaan Indonesia, Pemikiran tentang Pembinaan Kesadaran Sejarah. Jakarta: Kemendikbud, 2012.

[16] Juraid Abdul Latief, Manusia, Filsafat dan Sejarah. Jakarta: Bumi Aksara, 2006.

[17]A. Glencross, "Historical consciousness in international relation theory: a hidden disciplinary dialogue,". Paper in Millennium conf, University of Aberdeen, 2010.
[18]M. Kreuzer, "Historical knowledge and quantitative analysis: the case of the origins of proportional representation in American Political Science Review, vol. 104, pp. 369392, May 2010.

[19]B. J. Denison, History, Time, Meaning and Memory: Idea for Sociology of Religious, Leiden: Koninkjlijke Brill NV, 2011.

[20] Frances Pownall, Lessons from the Past: The Moral Use of History in fourth-century Prose, Michigan: University of Michigan Press, 2007.

[21] J. Elliott, "The limits of historical knowledge", in Eurepoen Review, vol. II, pp. 21-25, 2003.

[22]S. G. Grant, History lessons: teaching, learning, and testing in U.S. high school classrooms. New Jersey: Lawrence Erlbra-um Associate Publisher, 2003.

[23] J. Tosh, The Pursuit of History: Aim, Method, and New Directions in the Study of Modern History, $3^{\text {rd }}$ ed., London: Long-man Pearson Education, 2002.

[24] Chris Husband, A.. Kitson, \& A. Pendry, Understanding History Teaching, Philadelphia: Open University Press, 2003.

[25] Suhartono, Teori dan Metodologi Sejarah, Yogyakarta: Graha Ilmu, 2010.

[26]H. Sjamsuddin, Metodologi Sejarah, Yogyakarta: Ombak, 2007.

[27] Jeffrey A. Barash, Martin Heidegger and Problem of Historical Meaning, New York: Fordham University Press. 2003.

[28] Cohen, M. R. (1961). The meaning of human history. Chicago: The Open Court Publishing Company.

[29] William B. Russel, \& Anthony Pellegrino, "Constructing meaning from historical content: a research study," in Journal of Social Studies Research, 2008, vol. 32, pp. 3-13.

[30] Kuntowijoyo, Pengantar Ilmu Sejarah, Yogyakarta: Tiara Wacana, (2013).

[31]Gerald Mazabow, "The development of historical consciousness in the teaching of history in South Africa School, Unpub-lished.

[32]D. Greenberg, "Metahistory of everyday: historical consciousness in lived existence," Unpublished.

[33]R. L. Aiken, "Three coefficient for analyzing the reliability and validity of rating" in Educational and Psychological Measurement, vol. 45, pp. 131- 142, 1985. 